\title{
Structural Relationship between Brittle Deformation and Paleozoic to Mesozoic Basalt Dykes in the Precambrian Basement of the Southern Continental Part of the Cameroon Volcanic Line
}

\author{
Nicole Armelle Wambo Simeni ${ }^{*}$, Depesquidoux Tchaptchet Tchato ${ }^{2}$, Rose Noel Ngo Belnoun ${ }^{2}$, \\ Jean Pierre Tchouankoue ${ }^{2}$, Alembert Alexandre Ganwa1
}

${ }^{1}$ Department of Earth Sciences, University of Ngaoundere, Ngaoundere, Cameroon

${ }^{2}$ Department of Earth Sciences, University of Yaoundé I, Yaoundé, Cameroon

Email: *Simeni.wambo@yahoo.fr

How to cite this paper: Simeni, N.A.W., Tchato, D.T., Belnoun, R.N.N., Tchouankoue, J.P. and Ganwa, A.A. (2017) Structural Relationship between Brittle Deformation and Paleozoic to Mesozoic Basalt Dykes in the Precambrian Basement of the Southern Continental Part of the Cameroon Volcanic Line. International Journal of Geosciences, 8, 318-331.

https://doi.org/10.4236/ijg.2017.83016

Received: February 21, 2017

Accepted: March 24, 2017

Published: March 28, 2017

Copyright $\odot 2017$ by authors and Scientific Research Publishing Inc. This work is licensed under the Creative Commons Attribution International License (CC BY 4.0).

http://creativecommons.org/licenses/by/4.0/

\begin{abstract}
The work is a vivid description of the structural relationship between brittle deformation of the Precambrian basement in the southern continental part of the Cameroon Line and intrusive Paleozoic and Mesozoic basalt dykes swarms. A multidisciplinary approach that involves a combination of remote sensing techniques and field studies show that the major trend of brittle structures correspond to well-known regional structures: $\mathrm{N} 70^{\circ} \mathrm{E}$ (Adamawa Shear Zone), $\mathrm{N} 135^{\circ} \mathrm{E}$ (upper Benue trend) and $\mathrm{N} 30^{\circ} \mathrm{E}$ (Cameroon Volcanic Line) corresponding to E-W and N-S directions respectively. Basalt dykes are associated to NE-SW, E-W and NW-SE oriented fractures. An integration of the available information on brittle structures and basalt dykes directions suggest an emplacement of the Mesozoic and Paleozoic basalt dykes structurally controlled by Precambrian structures that were originated through Riedel's fracture kinematic model with dextral strike-slip Adamawa Shear Zone as the main shear zone during late stage of the Pan-African collision. Spatially, the restriction of the basalt dykes to the corridor of the Adamawa Shear Zone indicate that a rejuvenation of Precambrian faults may very well be the origin of the dykes with possibility that they may have been reworked several times during the Phanerozoic eon.
\end{abstract}

\section{Keywords}

Basalt Dykes, Brittle Tectonics, Adamawa Shear Zone, Riedel Model, Western Gondwana 


\section{Introduction}

The presence of basalt dyke swarms in any region is a surface expression of fractures of lithospheric importance and inversely provides a better understanding of these fracture distribution in the earth: This is considered as vectors of fissural eruptions channeling magma from source chamber to the Earth's surface. Dyke swarms may be characterized by up to several hundred intrusions, established almost simultaneously during a single intrusive event. These events are key indicators of geological processes and by extension, the reconstruction of ancient supercontinents [10]. Several authors believe that dyke swarms are remnants of supercontinent assembly: Rodinia and Gondwana for example [3] [36] [21] or of the establishment of volcanic structures [9] [17].

Basalt dykes of Paleozoic and Mesozoic age intrude the Precambrian basement in West Cameroon (Figure 1 and Figure 2), a basement bearing two lineaments of regional importance: 1 ) the $\mathrm{N} 70^{\circ} \mathrm{E}$ striking Adamawa Shear Zone (ASZ) also known as Central Cameroon Shear Zone (CCSZ) [25] which extends from the Gulf of Guinea in Central Africa to the Red Sea. The ASZ resulted from subduction-collision events (ca. $600-540 \mathrm{Ma}$ ) that involved the Congo-Sao Francisco Craton, West African Craton and Saharan Metacraton [1] [28]. It is well-known as the prolongation into Africa of the Pernambuco Shear Zone of North East Brazil after palinspatic reconstructions [23] before the opening of the South Atlantic Ocean during the Mesozoic [2] [53], 2) the Cameroon Volcanic Line (CVL) with a $\mathrm{N} 30^{\circ} \mathrm{E}$ orientation that runs from the Atlantic Ocean in the Gulf of Guinea to Lake Chad over a distance of more than $1500 \mathrm{~km}$. If abundant works document relations between the CVL and ASZ [19] [27] [31] [35], little is known concerning basalt dykes discovered only recently and for which the only information related to petrology and geochronology are available in [46] [47].

In the present study, brittle structures of the Precambrian basement are investigated as well as the intrusive basalt dykes in the West Cameroon area located in the ASZ corridor (Figure 1). This work involves geometrical and kinematic analyses of the brittle deformation of the basement in order to constrain the mechanism at the origin of the observed network of basalt dykes and to bring some answers to following major geological questions of the geology of the southern continental part of the Cameroon Volcanic Line:

- Does it exist relations between fracturation of the basement and the propagation of the basalt dykes?

- What are the links between the $\mathrm{N} 30^{\circ} \mathrm{E}$ direction of the $\mathrm{CVL}$ and the $\mathrm{N} 70^{\circ} \mathrm{E}$ direction of the Precambrian Adamawa Shear Zone?

- How can the studied basalt dykes help to explain the Paleozoic to Mesozoic crustal evolution in Cameroon?

\section{Geological Background}

The Precambrian terrane of west Cameroon is a polycyclic domain consisting of Paleoproterozoic to Archean high grade metamorphic rocks formed during the 2.1 Ga collision between Trans-Amazonian and Congo Cratons [38] [52] which 


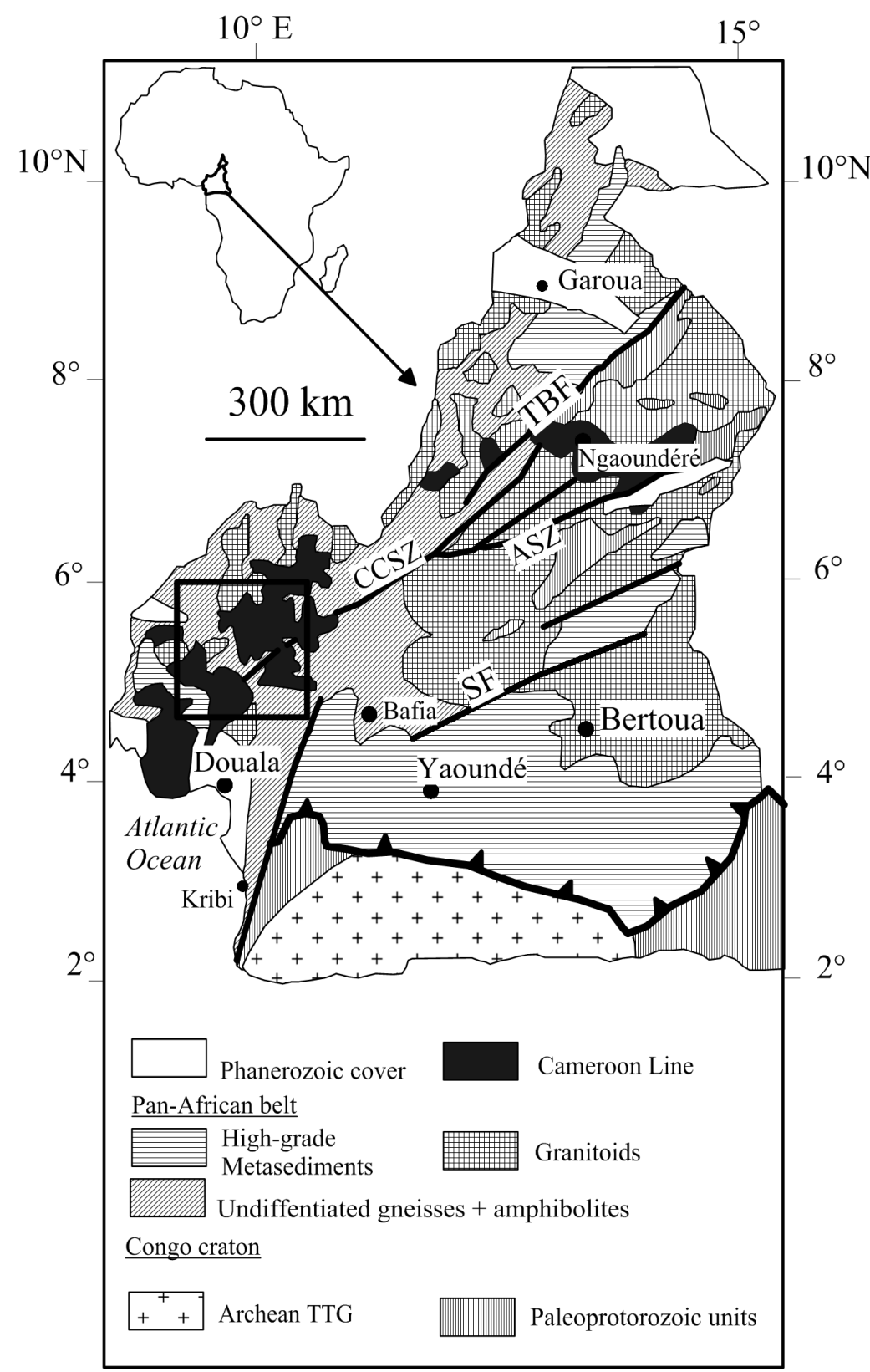

Figure 1. Geology map of Cameroon after [52]. The study area is indicated by the frame. SF: Sanaga Fault, ASZ: Adamawa Shear Zone, CCSZ: Central Cameroon Shear Zone, TBF: Tcholliré-Banyo Fault.

was remobilized during subsequent Pan-African orogeny [8]. The collision resulted in high grade metamorphic rock recrystallized under the amphibolite and granulites facies metamorphism [1] [37] [43] and crustal and mantle derived high-K calc-alkaline to shoshonitic, and alkaline affinity magma emplaced during 630 - $550 \mathrm{Ma}$ [20] [29] [44] [48] [51]. The chronology of the Pan-African tectonic evolution of the area is diversely interpreted. Some authors e.g. [28] [30] [34] suggest three deformation events which is characterized by an early crustal thickening (D1) constrained at 630 - 600 Ma manifested by a sub-horizontal S1 foliation and F1 fold [32]. This stage is followed by sinistral shearing movement 


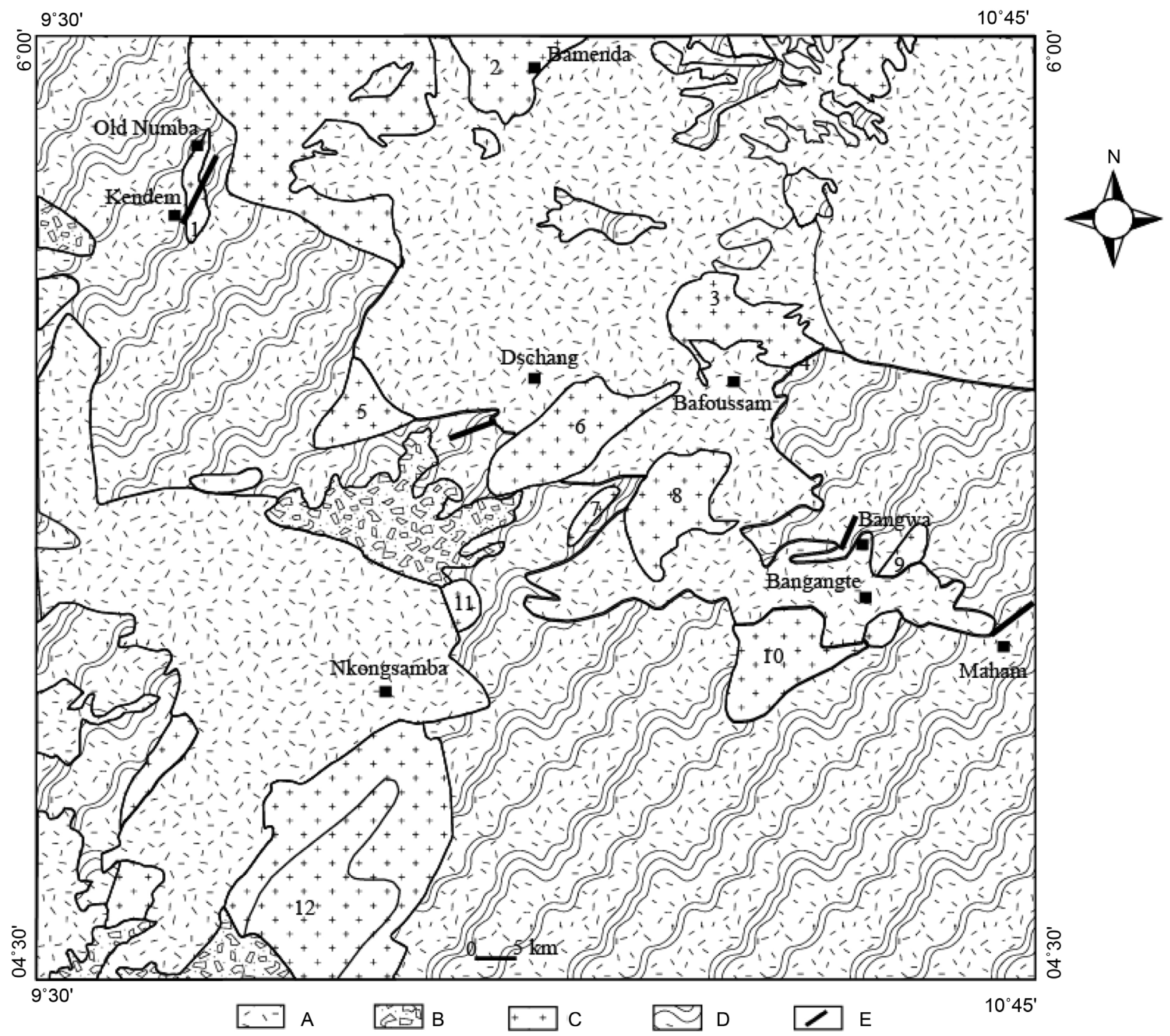

Figure 2. Reconnaissance geology map of West-Cameroon (Simplified after [54] with location of basalt dykes swarms. A = Tertiary volcanic rocks; $\mathrm{B}=$ Quaternary alluvial deposits; $\mathrm{C}=$ Pan-African granitoids; $\mathrm{D}=$ Undifferentiated gneiss; $\mathrm{E}=$ basalt dykes.

(D2) bracketed between 613 and $590 \mathrm{Ma}$ [14]. The dextral shearing movement constrained at $570-550 \mathrm{Ma}$ is underlain by $\mathrm{N} 30$ and $\mathrm{N} 70^{\circ} \mathrm{E}$ striking transpressional/transcurrent strike-slip shear zones [26] [31] [32] [34] [45] which is regarded as possible prolongations of the major shear zones of NE Brazil in a pre-drift Gondwana reconstruction [2] [24] [31]. [51] mentions a fourth deformation event $\left(\mathrm{D}_{4}\right)$ which is marked by $\mathrm{N} 80-110^{\circ} \mathrm{E}$ dextral and N160-180 ${ }^{\circ} \mathrm{E}$ sinistral shear zones which occur during the right lateral wrench movements (585 $540 \mathrm{Ma}$ ) mainly marked by the Adamawa Shear Zone. This shear zone is associated with a fracture network whose main trends are $\mathrm{N} 25-30^{\circ} \mathrm{E}, \mathrm{N} 70^{\circ} \mathrm{E}, \mathrm{W}-\mathrm{E}$, $\mathrm{N} 135^{\circ} \mathrm{E}$ in the Tombel area [33] Foumban [34] and Bafia [22]. Some of them are associated with tholeiitic basalt dykes in the Dschang, Maham, Kendem and Bangwa area, with whole rock ${ }^{40} \mathrm{Ar} /{ }^{30} \mathrm{Ar}$ ages ranging between $421.3 \pm 3.5$ and $149.2 \pm 3.8 \mathrm{Ma}$ (Tchouankoue et al., 2014). A SW-NE oriented alkaline igneous 
magmatism composed of anorogenic complex and floods basalt that partially covered both Paleoproterozoic and Pan-African formation; runs from Annobon Island in the Gulf of Guinea to Lake Chad that belong to the Cameroon Volcanic Line (CVL) and has been active since Eocene to Present [4] [49].

\section{Data and Methods}

The use of remote sensing data such as Shuttle Radar Topographic Mission (SRTM) is a good source for the mapping of topographic expression of tectolineaments [7] [12]. SRTM satellite images were used to extract lineaments. Image processing techniques such as directional filtering of Sobel $7 \times 7$ [6] [16] [39] for edge detection were used as well as shady relief methods and image enhancement by using Global Mapper 12 and X-Pro software. Lineaments with a minimum straight segment length of $500 \mathrm{~m}$ were mapped. The manual extraction of lineaments was performed while eliminating human-generated lineaments. The final lineament map is validated after comparison with field data. Global Mapper 12 and Geoplot were used for lineament statistical analyses. At the field scale, seven topographical maps (1/50.000 scale) have been used. A study of trends of lineaments was undertaken for rectilinear arms of rivers; the objective being to appreciate the various groups of fractures and their orientations separately inside granitoid massifs and the gneissic basement. Field data also include the orientation of the dykes. For detailed analysis, the studied area was divided into two sectors based on relative geological features: a Northwestern sector (sector 1) characterized by abundant Pan-African granitoids and a limited volcanic cover sector (sector 2) almost totally covered by volcanic rocks associated to Precambrian gneiss and granitoids (Figure 3).

\section{Results}

\subsection{Geometrical Analysis and Distribution of Lineament}

The statistical analysis revealed 1152 lineaments in the studied area (Figure 3). In sector 1, 242 lineaments were recorded with two main trending directions: $\mathrm{N} 30-40^{\circ} \mathrm{E}$ and NW-SE. Both directions are recorded in syn-tectonic granite plutons elongated and parallel to the N-S to NNE-SSW foliation, of the gneissic Precambrian basement rocks. These rocks are cut by sinistral NE-SW to NNESSW trending shear zones [50]. In sector 2, a rose diagram of 910 lineaments revealed three dominant trends: NE-SW, NW-SE and E-W. The NE-SW trending lineaments bear two lineaments continuous over more than $136 \mathrm{~km}$ through Bafoussam and Foumban cities (Figure 3). It matches with the Foutoni-Fondjomokwet Shear Zone [45] which is the SW prolongation of the Adamawa Shear Zone. Another NE-SW trending lineaments with a length of $55 \mathrm{~km}$, filled with quartzite is recorded at the southwest of the city of Bangangte (Figure 3).

These main trends are confirmed by the synthesis rose diagram and histogram (Figure 3 and Figure 4) which shows that the $\mathrm{N} 60^{\circ} \mathrm{E}$ oriented lineaments are the dominant set. This orientation contains various lineaments lengths, $>35 \mathrm{~km}$ and $15-35 \mathrm{~km}$ long lineaments are most dominant. These lineaments are predomi- 


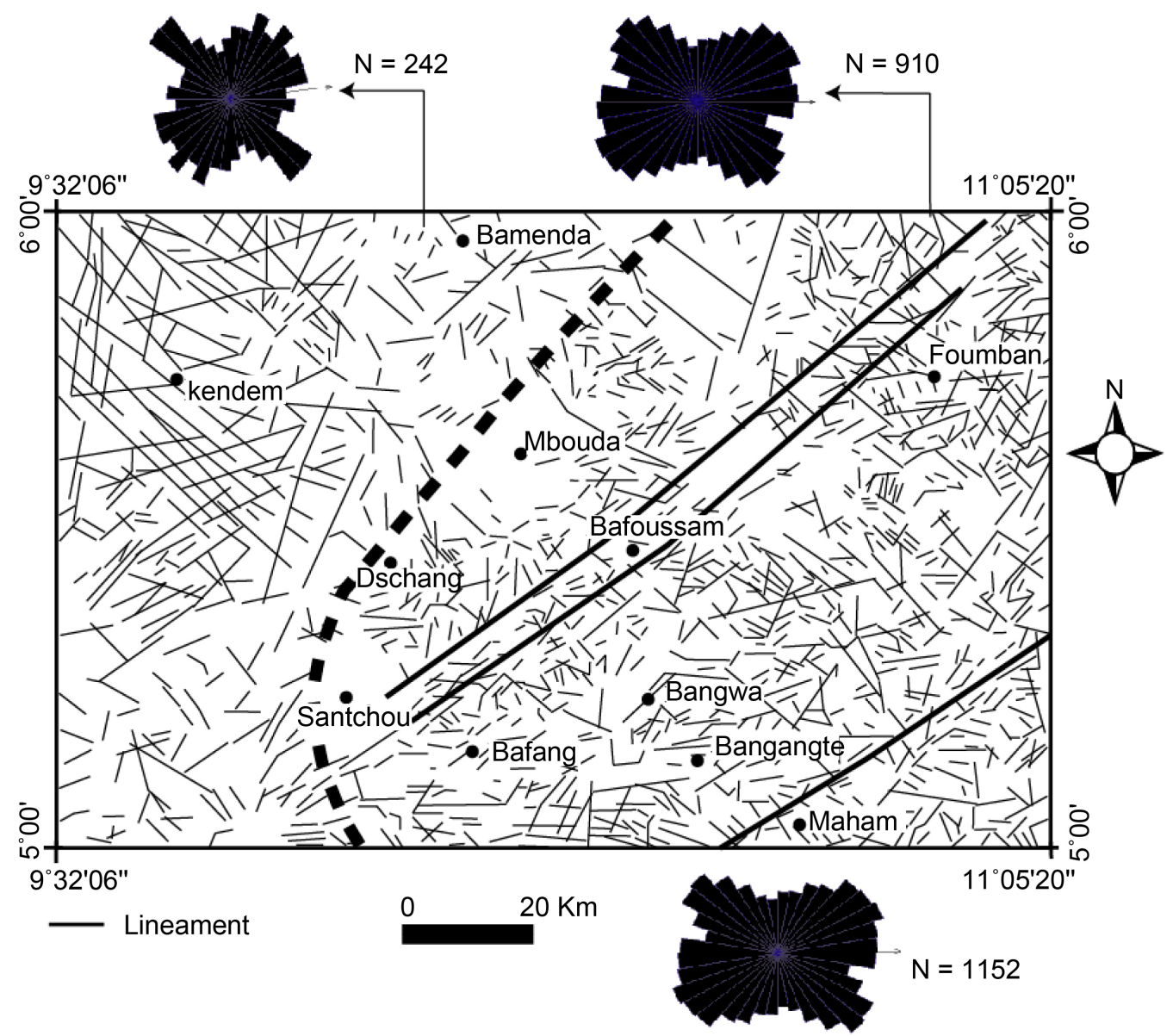

Figure 3. Map of lineaments. Bidirectional rose diagrams of lineaments in each sector. Number of measured elements $(\mathrm{N})$ is indicated within each rose diagram. Dash line delineates two sectors: sector I (North West), sector II (South East).

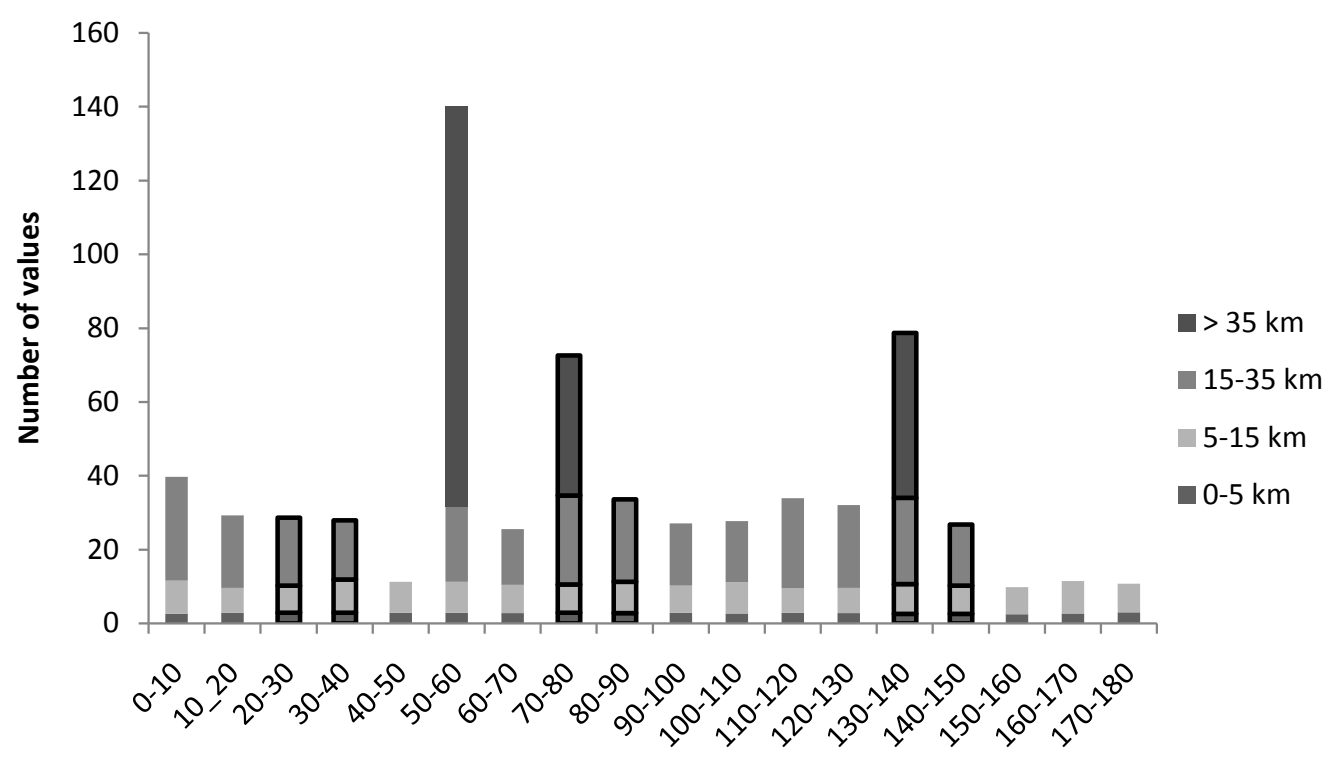

Direction

Figure 4. Lineaments characterisation: strikes and lengths based on the interpretation of structural map. Bold frame represent direction of basalt dykes. 
nantly observed in polycyclic metamorphic high grade and their orientations match with the N60-70 E striking ASZ [26] [34]. The conjugate sets of N70-80 ${ }^{\circ} \mathrm{E}$ and $\mathrm{N} 130-140^{\circ} \mathrm{E}$ striking lineaments are dominated by lineament of length greater than $35 \mathrm{~km}$ followed by $15-35 \mathrm{~km}$ long lineaments. These conjugate sets are widespread in both sectors. The N-S oriented lineaments contain $15-35 \mathrm{~km}$, $5-15 \mathrm{~km}$ and $0-5 \mathrm{~km}$ long lineaments which are widespread in the studied area.

\subsection{Geometrical Description of the Basalts Dyke}

Basalt dykes are widespread in the studied area. The contact between dykes and basement rocks is sharp and fluidal textures in the outer part of the dykes show that the dykes were emplaced in a liquid state and cooled at very low rates. Basalt dykes are widespread in the Precambrian gneiss and in late Pan-African granitoids of West Cameroon. Ten NNE-SSW trending basalt dykes are predominantly exposed in the northwest of the studied area at Batibo and Kendem between Bamenda and Mamfe (Figure 5(a)). They cut across syn-tectonic granite plutons elongated and parallel to the N-S to NNE-SSW foliation of the Precambrian gneissic basement rocks. These rocks are cut by sinistral NE-SW to NNE-SSW trending shear zones [50]. Similar NNE-SSW oriented basalt dyke are also found at Bangoua village located in the centre of the studied area. Their thickness is not greater than $30 \mathrm{~m}$ with a sub-vertical dip cut. These NNE-SSW oriented basalt dykes yielded ages between $200-140 \mathrm{Ma}$ [47]. The N70-90 ${ }^{\circ} \mathrm{E}$ and E-W oriented, sub vertical basalt dykes (Figure 5(b)) are restricted to sector 2 at Dschang and Maham and are usually of metric dimensions. They yielded a 420 $400 \mathrm{Ma}$ Paleozoic age [47]. N130 $\mathrm{E}$ and $\mathrm{N} 150^{\circ} \mathrm{E}$ oriented fractures are also filled with basalt. Figure 6 summarises the occurrence of basalt dykes in the NW-SE

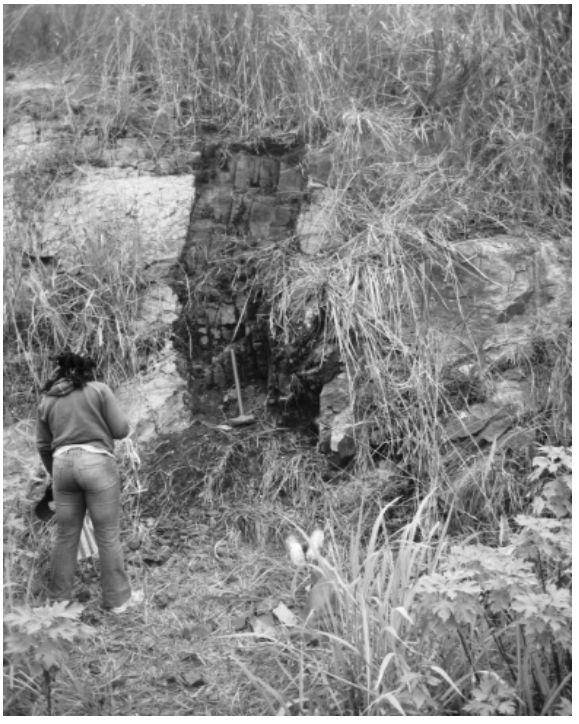

(a)

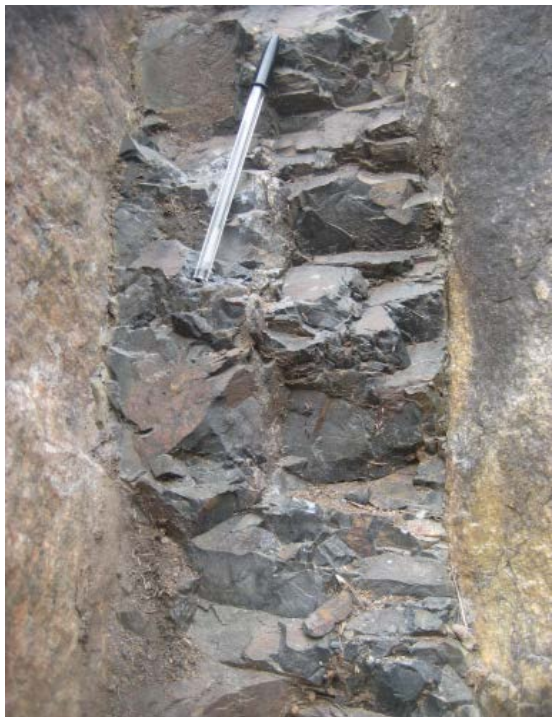

(b)

Figure 5. Basalt dyke outcrops. (a) Dyke trending $\mathrm{N} 70^{\circ} \mathrm{E}$ at Maham. Coordinates: $5^{\circ} 02^{\prime} 02^{\prime \prime} \mathrm{N} / 10^{\circ} 41^{\prime} 51^{\prime \prime} \mathrm{E}$ attitude: N70 $85^{\circ} \mathrm{N}$. (b) Dyke trending N25 ${ }^{\circ} \mathrm{E}$ at Bangoua. Coordinates: $5^{\circ} 12^{\prime} 20^{\prime \prime} \mathrm{N} / 10^{\circ} 27^{\prime} 04^{\prime \prime} \mathrm{E}$ attitude: N25E $35^{\circ} \mathrm{W}$. 


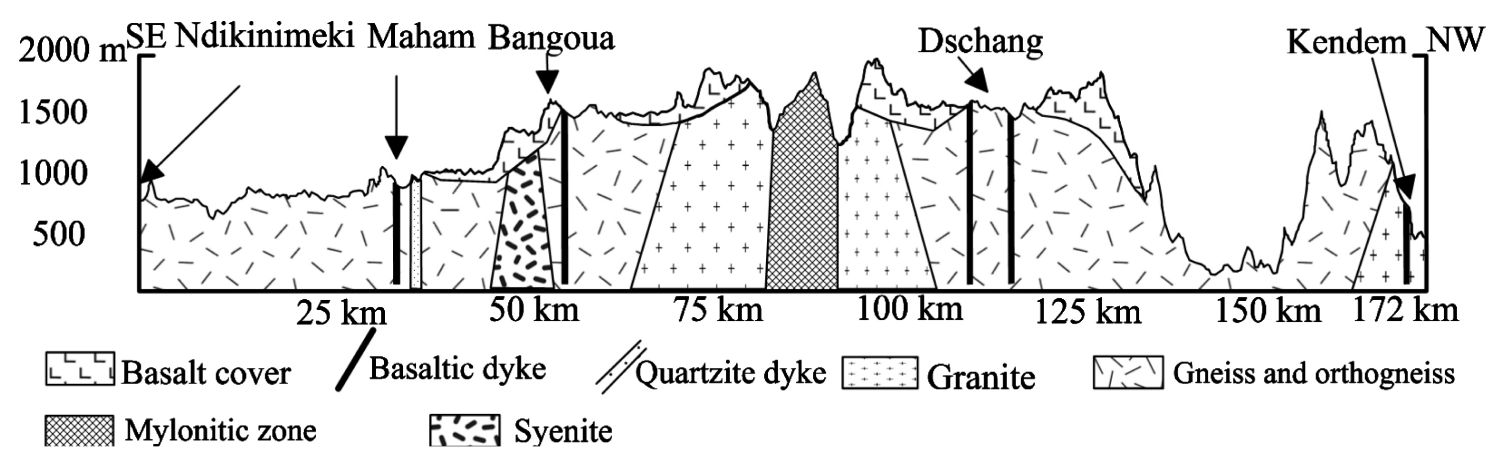

Figure 6. SE-NW cross section in the studied area (Basalt dykes not to scale).

cross section of the study area.

\section{Discussion}

\subsection{Kinematics of Faults Network}

As shown in paragraph 4.1, NNE-SSW, ENE-WSW, NW-SE and E-W striking lineaments are the main trends with ENE-WSW matching with the ASZ. Numerical modeling of the mode of deformation [5] [13] [18] [40] within strikeslip shear zone show that five direction families of associated fractures. P, R, R', $\mathrm{P}^{\prime}, \mathrm{Y}$ are formed from the main shear zone. $\mathrm{R}^{\prime}$ and $\mathrm{R}$ shear bands correspond respectively to synthetic and antithetic fractures which form an angle of $75^{\circ}$ and $15^{\circ}-20^{\circ}$ from the main shear zone (Figure 7). $\mathrm{P}^{\prime}$ and $\mathrm{P}$ shears are conjugate and $\mathrm{P}$ shears are symmetrical to $\mathrm{R}$ shears with respect to the main faults. Y shears are parallel to the main fault. Their geometrical relationship defines sinistral or dextral shearing movement. In the case of the studied area, the ENE-WSE striking shear zone is the main shear zone which corresponds to the ASZ. This shear zone forms an angle of around $20^{\circ}$ with the E-W trending fault conjugate with NW-SE oriented fractures. The geometrical arrangement between recorded fault networks is consistent with Riedel's fractures kinematic model as the main mode of deformation which is the origin of the observed fracture network. The reconstruction of stress field in this area is seen in Figure 7. From the above features $\mathrm{N} 85^{\circ} \mathrm{E}$ and $145^{\circ} \mathrm{E}$ are conjugate sets. It has been demonstrated that the maximal stress direction bisects a conjugate set at $30^{\circ}$ which implies that the maximum stress direction $(\sigma 1)$ matches the orientation NW-SE. N70-80 ${ }^{\circ} \mathrm{E}$ and $\mathrm{N} 80-90^{\circ} \mathrm{E}$ striking lineaments are conjugate sets of $\mathrm{N} 130-140^{\circ} \mathrm{E}$ and $\mathrm{N} 140-150^{\circ} \mathrm{E}$. This geometric arrangement of the main lineament trends show an angular relationship as follows: $15^{\circ}-20^{\circ}$ between ENE-WSW and N80-90 E, $75^{\circ}$ between ENEWSW and N140-150 $\mathrm{E}$ which is consistent with Riedel's shears [13]. Therefore, the NW-SW striking is the plausible orientation of the maximum stress because numerical modeling of brittle deformation shows that the maximum stress direction bisects the conjugate set at $30^{\circ}$. When applied in this case, the $\mathrm{N} 115^{\circ} \mathrm{E}$ corresponds to the maximum stress direction and the minimum stress direction is perpendicular to it which is NNE-SSW. Structural fingerprints of regional stress can therefore fit in a Riedel fracture model (Figure 7) characterized by 


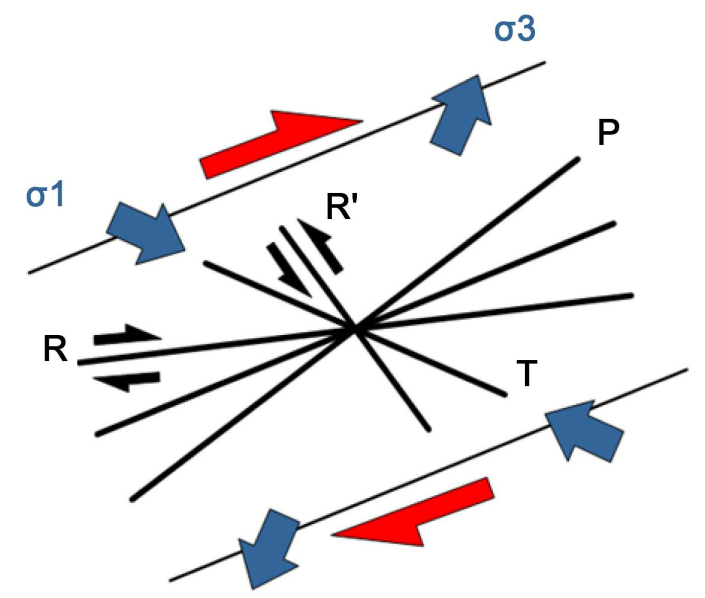

Figure 7. Riedel fracturation model of study area. $\mathrm{T}=$ $\mathrm{N} 115^{\circ}, \mathrm{R}^{\prime}=\mathrm{N} 145^{\circ}, \mathrm{R}=\mathrm{N} 85 ; \sigma 1=\mathrm{N} 135^{\circ}, \sigma 3=\mathrm{N} 45^{\circ}$, $\mathrm{P}=\mathrm{N} 55$.T: tension gashes; $\mathrm{R}$ and $\mathrm{R}^{\prime}$ : conjugate shear faults; P: symmetrical to R; $\sigma 3$ and $\sigma$ : tensional stress axes.

a NW-SE shortening $(\sigma 1)$ and a NNE-NE to NE-NW stretching ( $\sigma 3)$. Mega fractures appear mostly inside the Precambrian gneisses or at the contact between granites and country rocks and show ENE-WSW and NW-SE strike which correspond to the direction of the Cameroon Line $(\sigma 3)$, the Adamawa Shear Zone as superimposed shear and the Upper Benue $(\sigma 1)$ respectively. This kinematic model fit very well with that reported in the areas of Tombel [33] Bafia [22] and in Ngoura-colomines [42] sandwiched by $\mathrm{N}^{\circ} 0^{\circ} \mathrm{E}$ striking ASZ and Sanaga Fault (SF). The ubiquitous character of the Riedel's shears between ENE-WSW striking parallel CCSZ and SF suggest that they originated from the activity of this zone. The spatial distribution is also compatible with dextral shearing movement along both crustal shear zones that may be interpreted as shear zone boundaries.

\subsection{Basement Control on Paleozoic and Mesozoic Basalt Dykes Emplacement}

Field observations and brittle deformation studies show that basalt dykes are scarce in late Pan-African granitoids except in the Kendem area where the $\mathrm{N} 25-30^{\circ} \mathrm{E}$ trending basalt dykes are exposed in syn-tectonic granitoids. They are predominantly recorded in highly deformed Precambrian high grade gneiss where they are associated to $\mathrm{N} 25-30, \mathrm{~N} 70^{\circ} \mathrm{E}$ and $\mathrm{E}-\mathrm{W}$ which correspond respectively to $\mathrm{P}^{\prime}, \mathrm{R}$ and $\mathrm{R}^{\prime}$ in the Riedel's fractures kinematic model. Moreover, the contact between dykes and basement rocks is sharp and fluidal textures are recorded in outer part of the dykes. These fluidal textures are characteristic of emplacement in a liquid state at very slow cooling rates. The orientation of mineral at the outer part of the dykes is controlled by a fault wall. These features point to a structural control of the emplacement of Mesozoic and Paleozoic magmatism by pre-existent structures of which the geometrical arrangement is consistent with Riedel's structures kinematics. Furthermore, the stress field direction of this 
fault network is consistent with that of the last dextral shearing movement (D3 event) in the Central Africa fold belt [22] [34] [45]. This dextral shearing movement which was still active at $552 \mathrm{Ma}$ [43] following collision between West Africa and Congo Cratons [28] resulted in this fault network which controlled the emplacement of $\mathrm{N} 30^{\circ} \mathrm{E}$ oriented late Pan-African grani-toids [41] or NE-SW to $\mathrm{E}-\mathrm{W}$ transcurrent/transpressive movement that controlled the late pan-African granitization [15] [48]. Therefore, this fracture network is a heritage of the Pan-African deformation which has also served as pathways for Phanerozoic magma ascent. This argument is compatible with the tectonic model of the CVL of Moreau et al., 1987, which stated that the CVL corresponds to N30 ${ }^{\circ} \mathrm{E}$ tension gashes along Pan-African paleosutures [19] originated from the reactivation of Precambrian structures. This argument is supported by the geochronological data obtained from magmatic rocks associated to these paleostructures which show that the CVL was active from $82 \mathrm{Ma}$ to present [11] and was proceeded by Paleozoic (420 - $400 \mathrm{Ma}$ ) and Mesozoic (200 - $140 \mathrm{Ma}$ ) magmatic events [47].

\section{Conclusions}

The following main results can be summarised from the studies of the relationship between fracturation of the Precambrian basement and intrusive Paleozoic and Mesozoic basalt dykes in West Cameroon:

- Brittle structures in the Precambrian basement show the following major directions $\mathrm{N} 70^{\circ} \mathrm{E}, \mathrm{N} 135^{\circ} \mathrm{E} \mathrm{N} 30^{\circ} \mathrm{E}, \mathrm{N}-\mathrm{S}$ and E-W. Their spatial arrangement is consistent with a Riedel fractures kinematic model originating from dextral shearing movement along the ASZ related to collision between the Congo and West African Cratons.

- Basalts dykes are associated to NE-SW and E-W striking fractures with subvertical dips and mainly intrusive in gneissic rocks which are thought to have undergone brittle deformation during the formation of the Adamawa Shear Zone;

The basalt dykes as well as the Cameroon Volcanic Line may share a common origin in the reworking of Precambrian fractures during the Phanerozoic.

\section{Acknowledgements}

This study was carried out during the stay of the first author at the "Fakultät für Geowissenschaften, Geographie und Astronomie", Universität Wien; under an Ernst Mach Grant funded by the Austrian Federal Ministry of Science and Research (BMWF). We thank Bernhard Grasemann and Benjamin Huet (University of Vienna), Daniel Mege (Polish Academy of Sciences Institute of Geological Sciences, Research Centre in Wroclaw) for helpful discussions. Ryan Gallacher (University of Bristol), Ian Bastow (Imperial College-London) provided helpful comments that greatly improved the quality of the paper.

\section{References}

[1] Bouyo Houketchang, M., Penaye, J. Barbey, P., Toteu, S.F. and Wandji, P. (2013) 
Petrology of High Pressure Granulite Facies Metapelites and Metabasites from Tcholliré and Banyo Regions: Geodynamic Implication for the Central African Fold Belt (CAFB) of North-Central Cameroon. Precambrian Research, 224, 412-413.

[2] Brito Neves, B.B., Van Schmus, W.R. and Fetter, A. (2002) North-Western AfricaNorth Eastern Brazil: Major Tectonic Links and Correlation Problems. Journal of African Earth Sciences, 34, 275-278.

[3] Correa-Gomes, L.C. and Oliveira, E.P. (2000) Radiating 1.0 Ga Mafic Dyke Swarms of Eastern Brazil and Western Africa: Evidence of Post-Assembly Extension in the Rodinia Supercontinent? Gondwana Research, 3, 325-332.

[4] Deruelle, B., Ngounouno, I. and Demaiffe, D. (2007) The Cameroon Hot Line (CHL): A Unique Example of Active Alkaline Intraplate Structure in Both Oceanic and Continental Lithospheres. Comptes Rendus Géosciences, 339, 589-600.

[5] Diamantopoulos, A., Krohe, A. and Mposkos, E. (2009) Kinematics of Conjugate Shear Zones, Displacement Partitioning and Fragmentation of the Upper Rigid Crust during Denudation of High-P Rocks (Pelagonian and Sub-Pelagonian Zones, Greece). Tectonophysics, 473, 84-98.

[6] Drury, S.A. (1986) Remote Sensing of Geological Structure in Temperate Agricultural Terrains. Geological Magazine, 123, 113-121.

https://doi.org/10.1017/S0016756800029770

[7] Elmahdy, S.I. and Mohamed, M.M. (2016) Mapping of Tecto-Lineaments and Investigate Their Association with Earthquakes in Egypt: A Hybrid Approach Using Remote Sensing Data. Geomatics, Natural Hazards and Risk, 7, 600-619. https://doi.org/10.1080/19475705.2014.996612

[8] Ganwa, A.A., Klotzli, U.S. and Hauzenberger, C. (2016) Evidence for Archean Inheritance in the Pre-Pan-African Crust of Central Cameroon: Insight from Zircon Internal Structure and LA-MC-ICP-MS U-Pb Ages. Journal of African Earth Sciences, 120, 12-22.

[9] Geshi, N. (2008) Vertical and Lateral Propagation of Radial Dikes Inferred from the Flow-Direction Analysis of the Radial Dike Swarm in Komochi Volcano, Central Japan. Journal of Volcanology and Geothermal Research, 173, 122-134.

[10] Guiraud, R., Bosworh, W., Thierry, J. and Delpanque, A. (2005) Phanerozoic Geological Evolution of Northern and Central Africa: An Overview. Journal of African Earth Sciences, 43, 83-143.

[11] Itiga, Z., ChakamTagheu, P.J., Wotchoko, P., Wandji, P., Bardintzeff, J.M. and Bellon, H. (2004) La Ligne du Cameroun: Volcanologie et géochronologie de trois régions (mont Manengouba, plaine du Noun et Tchabal Gangdaba). Géochronique, 91, 13-16.

[12] Jordan, G. and Schott, B. (2005) Application of Wavelet Analysis to the Study of Spatial Pattern of Morphotectonic Lineaments in Digital Terrain Models. A Case Study. Remote Sensing of Environment, 91, 31-38.

[13] Katz, Y., Weinberger, R. and Aydin, A. (2004) Geometry and Kinematic Evolution of Riedel Shear Structures, Capitol Reef National Park, Utah. Journal of Structural Geology, 26, 491-501.

[14] Kwekam, M., Liégeois J.P., Njonfang, E., Affaton, P., Hartmann, G. and Tchoua, F. (2010) Nature, Origin and Significance of the Fomopéa Pan-African High-K Calc-Alkaline Plutonic Complex in the Central African Fold Belt (Cameroon). Journal of African Earth Sciences, 57, 79-95.

[15] Kwekam, M., Affaton, P., Bruguier, O., Liégeois, J.P., Hartmann, G. and Njonfang, E. (2013) The Pan-African Kekem Gabbro-Norite (West-Cameroon), U-Pb Zircon 
Age, Geochemistry and Sr-Nd Isotopes: Geodynamical Implication for the Evolution of the Central African Fold Belt. Journal of African Earth Sciences, 84, 70-88.

[16] Marion, A. (1987) Introduction Aux techniques de traitement d'images. Eyrolles, $278 \mathrm{p}$.

[17] Mège, D. and Korme, T. (2004) Fissure Eruption of Flood Basalts from Statistical Analysis of Dyke Fracture Length. Journal of Volcanology and Geothermal Research, 131, 77-92.

[18] Misra, S., Mandal, N. and Chakraborty, C. (2009) Formation of Riedel Shear Fractures in Granular Materials: Findings from Analogue Shear Experiments and Theoretical Analyses. Tectonophysics, 471, 253-259.

[19] Moreau, C., Regnoult, J.M., Deruelle, B. and Robineau, B. (1987) A New Tectonic Model for the Cameroon Line, Central Africa. Tectonophysics, 141, 317-334.

[20] Mosoh Bambi, C.K., Frimmel, H.E., Zeh, A. and Suh, C. (2013) Age and Origin of Pan-African Granites and Associated U-Momineralizations at Ekomedion, Southwest Cameroon. Journal of African Earth Sciences, 88, 15-37.

[21] Moulin, M., Aslalian, M. and Unternner, M. (2010) A New Starting Point for the South and Equatorial Atlantic Ocean. Earth Science Review, 98, 1-37.

[22] Mvondo Ondoa, J. (2009) Caractérisation des Evénements tectoniques dans le Domaine Sud de la chaine Panafricaine au Cameroun: Styles Tectoniques et Géochronologie des Séries de Yaoundé et Bafia. Thèse de Doctorat/PhD, Université de Yaoundé I, $162 \mathrm{p}$.

[23] Neves, S.P. (2003) Proterozoic History of the Borborema Province (NE Brazil): Correlations with Neighboring Cratons and Pan-African Belts, and Implications for the Evolution of Western Gondwana. Tectonics, 34, 1031.

[24] Neves, S.P., Rangel da Silva, J.M. and Mariano, G. (2005) Oblique Lineations in Orthogneisses and Supra Crustal Rocks: Vertical Partitioning of Strain in a Hot Crust (Eastern Borborema Province, NE Brazil). Journal of Structural Geology, 27, 15131527.

[25] Ngako, V., Jegouzo, P. and Nzenti, J.P. (1991) Le Cisaillement Centre Camerounais. Rôle structural et géodynamique dans l'orogenèse panafricaine. Comptes Rendus Academie Sciences, 313, 457-463.

[26] Ngako, V., Affaton, P., Nnange, J.M. and Njanko, T. (2003) Panafrican Tectonic Evolution in Central and Southern Cameroon: Transpression and Transtention during Sinsistral Shear Movements. Journal of African Earth Sciences, 36, 207-214.

[27] Ngako, V., Njongfang, E., Aka, T.F., Affaton, P. and Nnange, J.M. (2006) The North-South Paleozoic Trend of Alkaline Magmatism from Niger-Nigeria to Cameroon: Complex Interaction between Hotspots and Precambrian Faults. Journal of African Earth Sciences, 45, 241-251.

[28] Ngako, V., Affaton, P. and Njonfang, E. (2008) Pan-African Tectonics in Northern Cameroon: Implication for the History of the Western Gondwana. Gondwana Research, 14, 509-522.

[29] Ngo Belnoun, R.N. (2008) Petrology, Mineralogy, Geochemistry and Geochronology of the Kekem Mafic Complex, Western Cameroon. Unpublished PhD Thesis, University of Vienna, Austria, $189 \mathrm{p}$.

[30] Njanko, T., Nédélec, A., Kwékam, M., Siqueira, R. and Esteban, L. (2010) Emplacement and Deformation of the Fomopéa Pluton: Implication for the Pan-African History of Western Cameroon. Journal of Structural Geology, 32, 306-320.

[31] Njanko, T., Nedélec, A. and Affaton, P. (2006) Synkinematic High-K Calc-Alkaline Plutons Associated to the Pan-African Central Cameroon Shear Zone (West-Tibati 
Area): Petrology and Geodynamic Significance. Journal of African Earth Sciences, 44, 494-510.

[32] Njiekak, G., Dorr, W. and Tchouankoue, J.P. (2008) U-Pb Zircon and Micro Fabric Data of (Meta) Granitoids of Western Cameroon: Constraints on the Timing of Pluton Emplacement and Deformation in the Pan-African Belt of Central Africa. Lithos, 102, 460-477.

[33] Njome, M.S. and Suh, C.E. (2005) Tectonic Evolution of the Tombel Graben Basement, Southwestern Cameroon. Episodes, 28, 37-41.

[34] Njonfang, E., Ngako, V., Moreau, C., Affaton, P. and Diot, H. (2008) Restraining Bends in High Temperature Shear Zones: The "Central Cameroon Shear Zone", Central Africa. Journal of African Earth Sciences, 52, 9-20.

[35] Noutchogwe, T.C. (2004) Apport de la gravimétrie à l'étude de la bordure méridionale du plateau de l'Adamaoua (Cameroun). Thèse de Doctorat 3e Cycle, Université de Yaoundé I.

[36] Oliveira, E.P., Toteu S.F., Araujo, M.N.C., Carvalho, M.J., Nascimento, R.S., Bueno, J.F., McNaughton, N. and Basilici, G. (2006) Geologic Correlation between the Neoproterozoic Sergipano Belt (NE Brazil) and the Yaounde Belt (Cameroon, Africa). Journal of African Earth Sciences, 44, 470-478.

[37] Owona, S., Schulz, B., Ratschbacher, L., MvondoOndoa, J., Ekodeck, G.E., Tchoua, F.M. and Affaton, P. (2011) Pan-African Metamorphic Evolution in the Southern Yaoundé Group (Oubanguide Complex, Cameroon) as Revealed by EMP-Monazite Dating and Thermobarometry of Garnet Metapelites. Journal of African Earth Sciences, 59, 125-139.

[38] Penaye, J., Toteu, S.F., Tchameni, R., Van Schmus, W.R., Tchakounté, J., Ganwa, A., Miyem, D. and Nsifa, E.N. (2004) The 2.1 Ga West Central African Belt in Cameroon: Extension and Evolution. Journal African Earth Sciences, 39, 159-164.

[39] Prewitt, J.M.S. (1970) Object Enhancement and Extraction Picture Processing and Psychopictorics. Academic, New York, 75-149.

[40] Sara Coelho, S., Passchier, C. and Marques, F. (2006) Riedel-Shear Control on the Development of Pennant Veins: Field Example and Analogue Modeling. Journal of Structural Geology, 28, 1658-1669.

[41] Tagne-Kamga, G. (2003) Petrogenesis of the Neoproterozoic Ngondo Plutonic Complex (Cameroon, West Central Africa): A Case of Late-Collisional Ferro-Potassic Magmatism. Journal of African Earth Sciences, 36, 149-171.

[42] Takodjou, J.D.W., Ganno, S., Ngambu, A.A., Nomo, E.N., Mvondo, J.O. and Nzenti, J.P. (2016) Use of Landsat 7 ETM+ Data for the Geological Structure Interpretation: Case Study of the Ngoura-Colomines Area, Eastern Cameroon. Journal of Geosciences and Geomatics, 4, 61-72.

[43] Tchapchet, T.D., Schulz, B. and Nzenti, J.P. (2009) Electron Microprobe (EMP) Monazite Dating and P-T Data of the Neoproterozoic Metamorphic and Mylonitic Events in the Kekem Area, Cameroon North Equatorial Fold Belt. Neues Jahbur of Paleontology, 186, 95-109.

[44] Tchaptchet Tchato, D. (2011) Geology of the Kekem Area (Cameroon Central Domain): Metamorphic Petrology, P-T-t Path, EMP (monazite), LA-ICPMS (zircon) Dating and Implications for the Geodynamic Evolution of the Pan-African North Equatorial Fold Belt. Thèse Doctorat/PhD, Université de Yaoundé I, 109 p.

[45] Tcheumenak Kouémo, J., Njanko, T., Kwékam, M., Naba, S., Nké, B.E.B., Sandjo, A.F.Y., Fozing, E.M. and Njonfang. E. (2014) Kinematic Evolution of the Fodjomekwet-Fotouni Shear Zone (West-Cameroon): Implications for Emplacement of 
the Fomopéa and Bandja Plutons. Journal of African Earth Sciences, 99, 261-275.

[46] Tchouankoue, J.P., Simeni Wambo, N.A., Kagou Dongmo, A. and Wörner, G. (2012) Petrology, Geochemistry, and Geodynamic Implications of Basalt Dyke Swarms from the Southern Continental Part of the Cameroon Volcanic Line, Central Africa. The Open Geology Journal, 6, 72-84. https://doi.org/10.2174/1874262901206010072

[47] Tchouankoue, J.P., Simeni Wambo, N.A., Kagou Dongmo, A. and Li, X.-H. (2014) 40Ar/39Ar Dating of Basalt Dykes Swarm in Western Cameroon: Evidence of Late Paleozoic and Mesozoic Magmatism in the Corridor of the Cameroon Line. Journal of African Earth Sciences, 93, 14-22.

[48] Tchouankoue, J.P., Li, X.H., Belnoun, R.N.N., Mouafo, L. and Ferreira, V.P. (2016) Timing and Tectonic Implications of the Pan-African Bangangte Syenomonzonite, West Cameroon: Constraints from in-Situ Zircon U-Pb Age and Hf-O Isotopes. Journal of African Earth Sciences, 124, 94-103.

[49] Tchuimegnie Ngongang, N.B., Kamgang, P., Chazot, G., Agranier, A., Bellon, H. and Nonnotte, P. (2015) Age, Geochemical Characteristics and Petrogenesis of Cenozoic Intraplate Alkaline Volcanic Rocks in the Bafang Region, West Cameroon. Journal African Earth Sciences, 102, 218-232.

[50] Tetsopgang, S., Enami, M. and Njonfang, E. (2011) Emplacement P-T Condition Pan-African Biotite-Amphibole Granitoids in the Nkambe Area, Cameroon. Journal of Mineralogical and Petrological Sciences, 106, 306-319. https://doi.org/10.2465/jmps.110308

[51] Toteu, S.F., Penaye, J. and Djomani Poudjom, Y. (2004) Geodynamic Evolution of the Pan-African Belt in Central Africa with Special Reference to Cameroon. Canadian Journal of Earth Sciences, 41, 73-85. https://doi.org/10.1139/e03-079

[52] Toteu, S.F., Van Schmus, W.R., Penaye, J. and Michard, A. (2001) New U-Pb and Sm-Nd Data from North-Central Cameroon and Its Bearing on the Pre-Pan African History of Central Africa. Precambrian Research, 108, 45-73.

[53] Van Schmus, W.R., Oliveira, E.P., Da Silva Filho, A., Toteu, S.F., Penaye, J. and Guimarães, I.P. (2008) Proterozoic Links between the Borborema Province, NE Brazil, and the Central African Fold Belt. Geological Society London Special Publications, 294, 69-99. https://doi.org/10.1144/SP294.5

[54] Weecksteen, G. (1957) Carte géologique de reconnaissance à l'échelle du 1/500.000 Territoire du Cameroun, Douala Est. Dir. Mines Géol. Cameroun, Paris.1 carte et notice explicative. Imprimerie Nationale de Yaoundé, 35 p. 
Submit or recommend next manuscript to SCIRP and we will provide best service for you:

Accepting pre-submission inquiries through Email, Facebook, LinkedIn, Twitter, etc. A wide selection of journals (inclusive of 9 subjects, more than 200 journals)

Providing 24-hour high-quality service

User-friendly online submission system

Fair and swift peer-review system

Efficient typesetting and proofreading procedure

Display of the result of downloads and visits, as well as the number of cited articles Maximum dissemination of your research work

Submit your manuscript at: http://papersubmission.scirp.org/

Or contact ijg@scirp.org 